\title{
The Giant Asian Mantis Hierodula tenuidentata Saussure, 1869 spreads in Italy: a new invasive alien species for the European fauna? (Insecta Mantodea)
}

\author{
Roberto Battiston ${ }^{*}$, Fausto Leandri², William di Pietro ${ }^{3} \&$ Simone Andria ${ }^{2}$
}

${ }^{1}$ Musei del Canal di Brenta, Palazzo Perli, via Garibaldi 27, 36020, Valstagna, Vicenza, Italy; e-mail: roberto.battiston@, museivalstagna.it

${ }^{2}$ World Biodiversity Association Onlus, c/o Museo Civico di Storia Naturale, Lungadige Porta Vittoria 9, Verona, Italy

${ }^{3}$ Associazione Culturale Arthropoda Live Museum, via Modena 1, 20099, Sesto San Giovanni, (Milano), Italy

${ }^{*}$ Corresponding author

ABSTRACT

The presence of the Giant Asian Mantis, Hierodula tenuidentata Saussure, 1869 (Insecta Mantodea), is here reported for the first time in Italy. A well settled and probably wide spread population of this species is here described in detail, evaluating the increase in the number of individuals in the recent years and its adaptability to the European continental climate and to anthropized environments. The synonymy of this species with $H$. transcaucasica Brunner von Wattenwyl, 1878 is here discussed and some considerations on the potential impacts on the local ecosystems and its future spreading in Europe as an invasive species are here given.

KEY WORDS

Conservation; Distribution; Hierodula; Alien Species; Mantodea.

Received 25.10.2018; accepted 13.11.2018; printed 30.12.2018; published online 07.01.2019

\section{INTRODUCTION}

The Giant Transcaucasian Mantis (Hierodula transcaucasica Brunner von Wattenwyl, 1878) originally described for the North-East of Iran, showed a typically Asian distribution until a few years ago: Afghanistan, Caucasus, Iran, Central Asia (Ehrmann, 2002; Battiston \& Massa, 2008) until reaching westward the Crimea (Werner, 1916) where, however, after Werner's reporting, it was no longer recorded, if not in recent years, with a considerable presence and a potential expansion in Ukraine (Pushkar \& Kavurka, 2016). In the southernmost areas of its range, it has been recorded in Eastern Turkey since the seventies (Ehrmann, 2011) approaching the Mediterranean Europe.

Between 2015 and 2018, H. transcaucasica was recorded as in expansion in several Balkan locations reaching the Greek islands (Cianferoni et al., 2018; Romanowski et al., in press). Until the recent expansions to the West this species has been little considered in the scientific literature: the male allotype was only described recently (Battiston \& Massa, 2008) and its taxonomic identity has been rediscussed in the last years suggesting the synonymy with the Giant Asian Mantis H. tenuidentata Saussure, 1869 (Ehrmann, 2011; Ehrmann \& Borer, 2015; Schwarz et al., 2018). The distribution of $H$. tenuidentata is traditionally located between India and Central Asia (Schwarz et al., 2018), but the synonymy with $H$. transcaucasica would expand it to Caucasus reaching the Mediterranean.

In this scenario, the doubtful attribution of some specimens recently recorded in Europe (Cianferoni 
et al., 2018, van der Heyden, 2018a, 2018b), created additional confusion on this mantid, its distribution and its status of alien or native species: imported with cargos from Asia or arrived with a natural expansion from Caucasus.

The taxonomy of these mantids is here discussed presenting new data in support of the synonymy between the two species and the presence of several new records in different locations of Northern Italy. This work describes and discusses the first Italian stable and reproductive population found in the Po valley, with a first overview on its possible impacts on the local ecosystems and spread potential in Italy and Europe.

\section{MATERIAL AND METHODS}

The presence of $H$. tenuidentata was recorded in the Po Valley in two ways. First, the presence of individuals and oothecae posted or reported on social media (Facebook, Messenger, iNaturalist) was recorded and listed. In this case the observations used were verified through clear photographic material where the diagnostic characters were evident or a direct contact with the author of the observation and a following on-site verification, were possible. Second, the population located in the province of Cremona was investigated in detail, using field surveys and transects for the count of the number of specimens and oothecae in the area where the presence of this species was observed. To have a first estimate of the increase of the local population over the years, a standardized count (1 hour of slow walking) over a define transect of 900 meters has been done, recording separately the recently laid oothecae (not hatched) and the old oothecae laid in the past years (already hatched)

ABBREVIATIONS. coll. $=$ collection; juv. $=$ juvenes; $\mathrm{ex} / \mathrm{x}=$ specimen $/ \mathrm{s}$; obs. = personal observation.

\section{RESULTS}

For the province of Cremona (Italy), a total of 33 individuals and 119 oothecae were recorded in an area of about $200 \mathrm{~km}^{2}$ : Calvatone: 17.IX.2018, 1 female, coll. Leandri; 17.IX.2018, 1 ootheca, obs.; 5.IX.2018, 1 female, obs.; Cingia de Botti: 12.IX.2018, 1 female, obs.; 29.VII.2018, 1 juv., obs.; 9.X.2018, 1 female, coll. Leandri; 9.X.2018, 1 ootheca, coll. Leandri; 9.X.2018, 2 oothecae, obs.; Cremona: 7.X.2018, 1 female, obs.; Drizzona: 13.VIII.2018, 1 female, 2 males, obs.; Piadena: 25.VI.2018, 1 juv., obs.; 30.IX.2018, 1 female, obs.; 5.X.2018, 3 ootheche, obs.; San Giovanni in Croce: 1.XI.2017, 1 ootheca, obs.; 10.IX.2018, 1 female, coll. Leandri; 12.IX.2018, 1 ex, coll. Leandri; 14.IX.2016, 1 female, obs.; 16.VIII.2018, 1 female, coll. Leandri; 18.VIII.2018, 1 female, obs.; 18.VIII.2018, 1 male, obs.; 19.IX.2018, 1ex, obs.; 24.VIII.2018, 1 female, obs.; 24.VIII.2018, 1 juv., obs.; 26.IX.2018, 1 female, obs.; 27.IX.2018, 1 female, coll. Leandri; 27.IX.2018, 1 female, obs.; 27.IX.2018, 2 oothecae, coll. Leandri; 3.IX.2018, 1 ex., obs.; 30.IX.2018, 1 female, obs.; 5.X.2018, 103 oothecae, obs.; 5.X.2018, 5 female, coll. Leandri; 7.X.2018, 5 oothecae, obs.; 7.VII.2018, 1 juv., obs.; 14.X.2018, 1 female, obs.; Scandolara Ravara: 25.VIII.2018, 1 male, obs;

Canneto sull'Oglio (Mantova province): 28.VI.2018, 1 juv., obs.

In addition to the discovery of oothecae already hatched and laid in the past years, adult specimens have been recorded in the area since 2016, demonstrating its ability to overwinter and reproduce (Figs. 1-3) continuously with a stable population. The count of the oothecae in the transect recorded 18 oothecae laid in the past years and 69 still unhatched and undamaged, presumably laid in 2018 , with an estimated increase in the population of $383 \%$ in this year over the past.

The collecting and observation areas in the province of Cremona show a marked preference of this species for the few wooded areas (Fig. 4: 75\%), over the other environments included in strongly cultivated countryside landscape. Wooded strips were preferred especially as an habitat suitable for the aggregation of the females when approaching the ootheca laying time (Fig. 2). This situation is expected, since this species has repeatedly shown a preference for deposition on trees or stable vegetation, unlike for example Mantis religiosa Linnaeus, 1758 , which seems to prefer more flat and hard surfaces such as stones or man-made artefacts (Battiston, unpublished data). Wandering individuals showed on the contrary a preference for vegetated environments but also with high anthropogenic impact such as house gardens and vegetable gardens (Fig. 5: 52\%). 

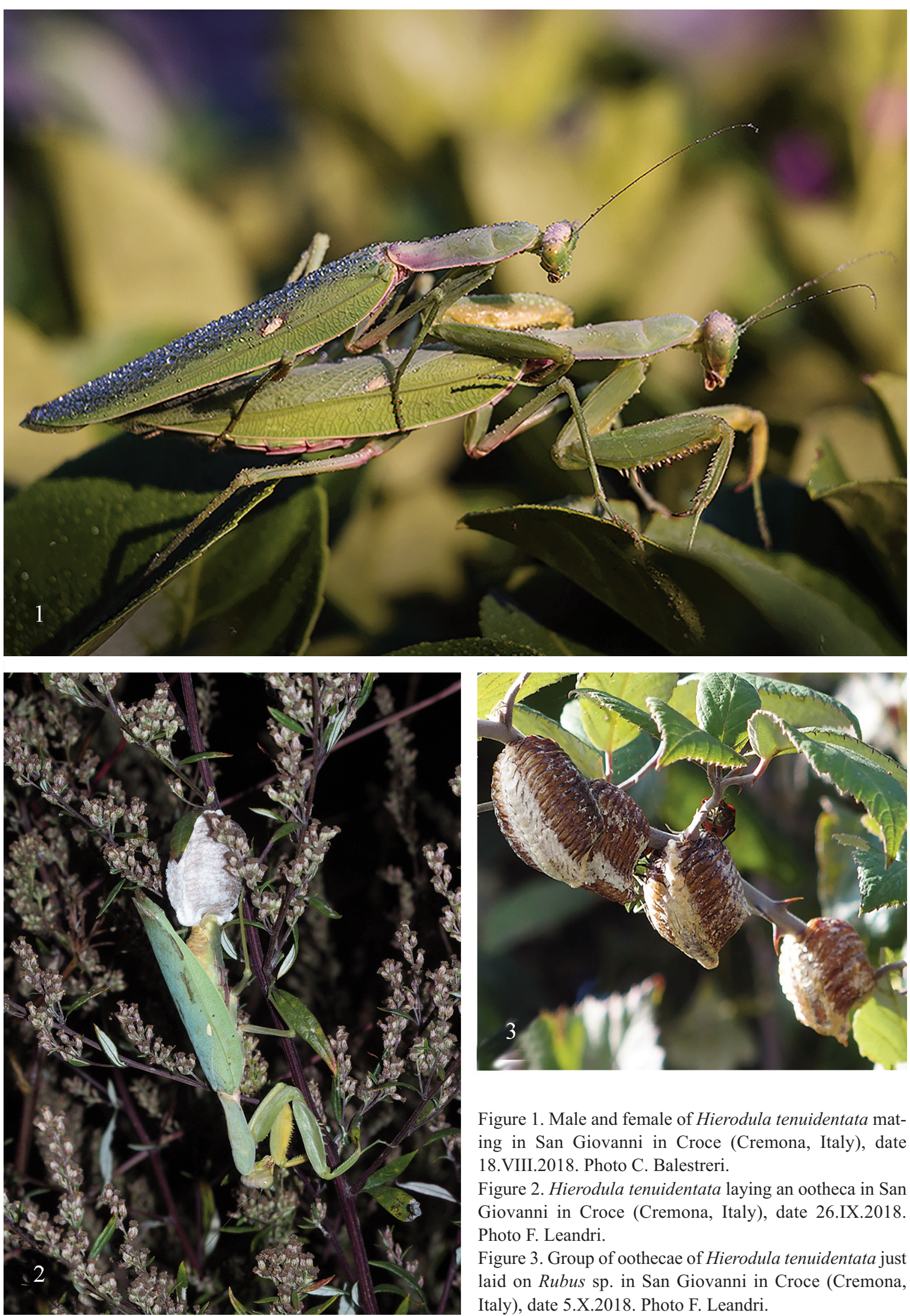

Figure 1. Male and female of Hierodula tenuidentata mating in San Giovanni in Croce (Cremona, Italy), date 18.VIII.2018. Photo C. Balestreri.

Figure 2. Hierodula tenuidentata laying an ootheca in San Giovanni in Croce (Cremona, Italy), date 26.IX.2018. Photo F. Leandri.

Figure 3. Group of oothecae of Hierodula tenuidentata just laid on Rubus sp. in San Giovanni in Croce (Cremona, Italy), date 5.X.2018. Photo F. Leandri. 


\section{TAXONOMICAL REMARKS}

The synonymy of $H$. transcaucasica with $H$. tenuidentata has been discussed in recent years

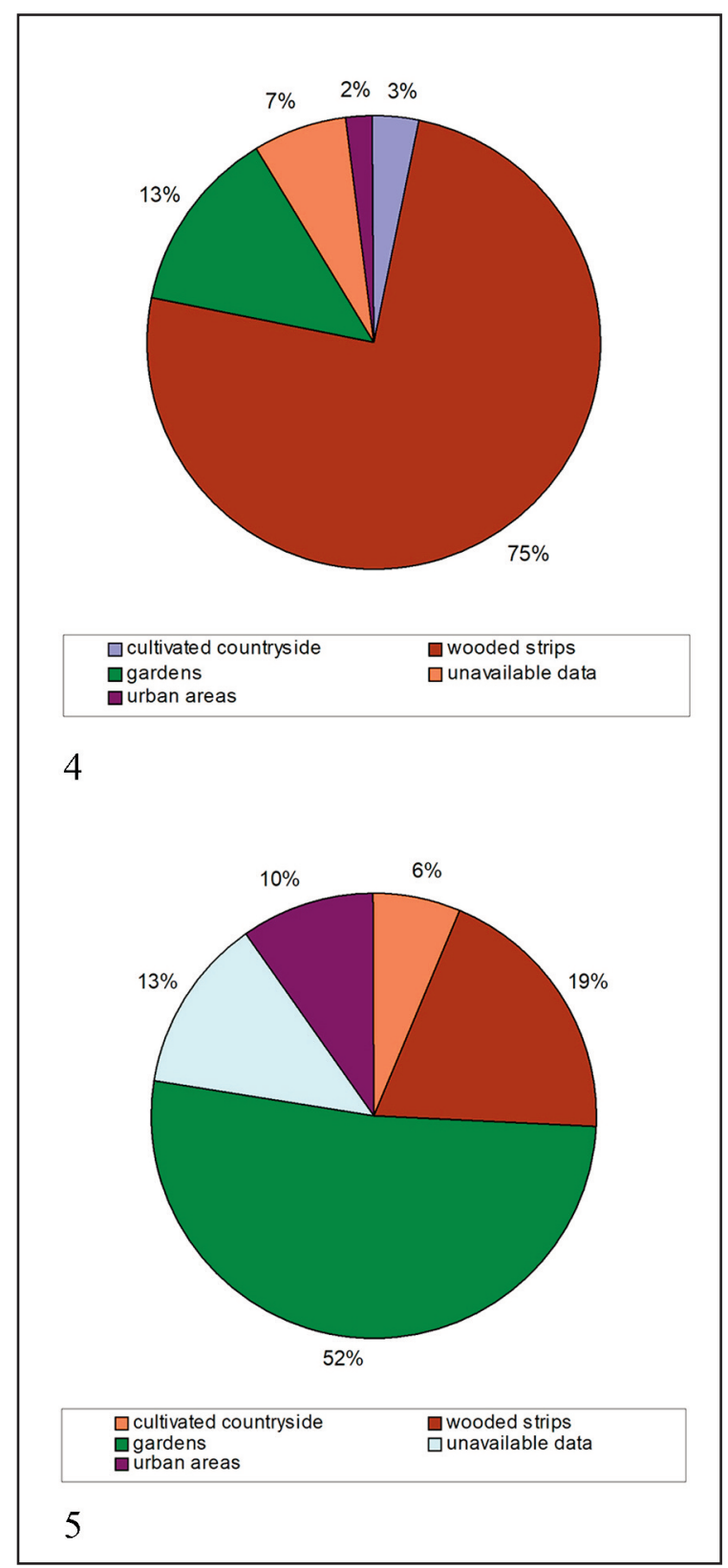

Figure 4. Habitat of the observation of individuals and oothecae of Hierodula tenuidentata from the Cremonese population (Italy), identified as: cultivated countryside, gardens, wooded strips, urban areas and unavailable data.

Figure 5. Habitat of the observation of wandering individuals of Hierodula tenuidentata from the Cremonese population Italy), identified as: cultivated countryside, gardens, wooded strips, urban areas and unavailable data.
(Ehrmann, 2011; Ehrmann \& Borer, 2015) in particular referring to the comparison with the female type housed in the NHMW and some specimens collected in Nepal (Schwarz et al., 2018). However these authors pointed out that a comparison with many more specimens across the distributional ranges of both species was needed to confirm this status. At present, other than approximate remarks to shape and dimensions, the only objective character useful to separate the two species: H. transcaucasica from $H$. tenuidentata is the presence of completely black discoidal spines on the fore femora in the first and spines black only in the tip in the latter (Giglio-Tos, 1911, 1927). In our research, by the discontinuity from their natural ranges, we examined many specimens collected in the wild coming from what is probably a single isolated population. In the natural variability of this population we examined specimens with all the possible shades in the shapes, sizes and spines: from entirely black spines to spines black only in the tip. This last character is clearly not valid to separate these species. The examination of the male genitalia of a partially blackspined specimen, resulted with no appreciable differences with the black-spined male allotype genitalia described from Caucasus (Battiston \& Massa, 2008). For these reasons we decide to support the synonymy and consider $H$. tenuidentata a single species distributed from India to Europe.

\section{DISCUSSION}

Considering the rapid spreading of this species to the western countries in recent years, starting from the Caucasian areas to Europe, its arrival in Italy was predictable, even if the dynamics are still not clear at present. Considering the present distribution of this species in Europe ranging from Ukraine to Greece and reaching west Albania (Van der Heyden, 2018), but with the apparent absence of data for the Dalmatian area, despite the recent mantidological investigations (see e.g. Romanowsky \& Romanowsky, 2014; Rebrina et al., 2014; Pavićević et al., 2014) and monitoring on social media, which would represent in some way a spatial continuity with the native range of this species, it is probable that this is not a natural expansion of the Ukraine populations but of a manmediated transport. Since this species is not 
commonly reared as pet, and therefore its voluntary release in nature seems improbable, the arrival through mercantile channels seems the most probable hypothesis, with dynamics, however, all to be ascertained. The fact that in the Cremonese area there is a vital population active since at least 2016 able to overwinter in an area characterized by a continental climate such as the Po Valley suggests that the origin is from populations located at the same latitudes, in the northernmost areas of this species, like Ukraine or the Caucasian provinces of Russia, but it is not possible to exclude a commercial route of passage for Greece, an important commercial window over the whole Mediterranean area.

The impact of this species on the Italian as well as on the European ecosystems is also currently unknown. It should however be emphasized that in the area here considered other mantid species are present: Mantis religiosa with a well established population and, since few years, and in smaller numbers, even the more Mediterranean dwarf mantid Ameles spallanzania Rossi, 1792, a more uncommon species, but also in a slow expansion phase from the Mediterranean towards the Continental Europe (Leandri et al., 2013). The abundance of oothecae here discovered (Fig. 3) and the well settled population of $H$. tenuidentata, are compatible if not greater than a well settled population of Mantis religiosa. This may presage a possible competition between these species, for space and resources, considering the strong ecological proximity of these two species, both well adapted to an already well anthropized environment and the almost perfect overlapping of the life cycle with wintering oothecae and adults active between August and October. The systematic proximity also lead to assume a possible interference in reproduction. Both are species where sexual cannibalism and attraction through pheromones, whose species-specificity is still under investigation, are well used in matings. It is known that the males of Mantis religiosa respond positively to the pherormonic signals coming from other mantids species, even if not phylogenetically closely related, such as Tenodera Burmeister, 1838 (Leito \& Brown, 2008). It is therefore easy to suppose that $H$. tenuidentata, may represent a potential obstacle to the reproduction of the native species, and representing for them a real threat, as already observed in other mantid species victims of competition with invasive alien species (Fea et al., 2013).
The impact of this species on the other animals are also unknown but Hierodula is a voracious predator, more massive than Mantis religiosa, able to prey a large number of invertebrates and also small vertebrates, showing a remarkable ability to adapt to different preys and with a strong potential impact on local communities (Battiston et al., 2018). Moreover between September and October 2018 some occasional and unconfirmed records of this species have been posted on the internet in the area of Parma, continuous to the Cremonese area, showing that the presence of this species in Italy may be underestimated and ready to spread in other European countries using commercial routes. In this sense the citizen-science based monitoring is strongly encouraged to be able to follow the rapid spreading of this species.

\section{ACKNOWLEDGEMENTS}

We would like to thank all the collectors of the observations for sharing useful records and pictures of the mantids: Carlo Balestreri, Giacomo Galli, Cristina Gamba, Gabriele Leandri (San Giovanni in Croce, Italy), Daniela Benedetti, Francesco Cecere, Fabrizio Lanfredi (Calvatone, Italy), Andrea Marchesini (Scandolara Ravara, Italy); Vanna Brunoni (Piadena, Italy); Gabriele Busseti (Drizzona, Italy) Paolo Marenzi (Cremona, Italy); Simone Ravara (Cingia de Botti, Italy). A special thanks to Marco Bardiani (Marcaria, Italy) and Bruno Massa (Palermo, Italy) for their help and to the World Biodiversity Association onlus for the support in this manuscript

\section{REFERENCES}

Battiston R. \& Massa B., 2008. The Mantids of Caucasus (Insecta Mantodea). Atti dell'Accademia Roveretana degli Agiati, a. 258, ser. VIII, vol. VIII (B): 5-28.

Battiston R., Picciau L., Fontana P. \& Marshall J., 2010. The Mantids of the Euro-Mediterranean Area. WBA Handbooks 2, Verona, 240 pp.

Battiston R., Andria S. \& Ruzzante G., 2017. The silent spreading of a giant mantis: a critical update on the distribution of Sphodromantis viridis (Forskål, 1775 ) in the Mediterranean islands (Mantodea: Mantidae). Onychium, 13: 253-30. DOI: 10.5281/ zenodo. 546318 
Battiston R., Puttaswamaiah R. \& Manjunath N., 2018. The fishing mantid: predation on fish as a new adaptive strategy for praying mantids (Insecta: Mantodea). Journal of Orthoptera Research, 27: 155-158. DOI: 10.3897/jor.27.28067

Cianferoni F., Mochi O. \& Ceccolini F., 2018. New records of Hierodula Burmeister, 1838 (Mantodea: Mantidae) in Europe. Revista gaditana de Entomología, 9: 299-308

Ehrmann R., 2002. Mantodea Gottesanbeterinnen der Welt. NTV Wissencraft, Munster, 519 pp.

Ehrmann R., 2011. Mantodea from Turkey and Cyprus (Dictyoptera: Mantodea). Articulata, 26: 1-42.

Ehrmann R. \& Borer M., 2015. Mantodea (Insecta) of Nepal: an annotated checklist. In: Hartmann M. \& Weipert J. (Eds), Biodiversität \& Naturausstattung im Himalaya. Bd. V., pp. 227-274.

Fea M.P., Stanley M.C. \& Holwell G.I., 2013. Fatal Attraction: Sexually Cannibalistic Invaders Attract Native Mantids. Biology Letters, 9, 20130746. DOI: 10.1098/rsbl.2013.0746

Giglio-Tos E., 1911. Mantidi esotici. v. Mantes, Tenoderae, Hierodulae, Rhomboderae. Bollettino della Società Entomologia Italiana: 3-167.

Giglio-Tos E., 1927. Orthoptera, Mantidae Das Tierreich, Berlin - Leipzig, 707 pp.

Leandri F., Bardiani M. \& Battiston R., 2013. Nuova segnalazione di Ameles spallanzania (Rossi, 1792) (Insecta, Mantodea) in Pianura Padana. Pianura, 31: $117-120$

Leito J.P. \& Brown W.D., 2008. Mate attraction by females in a sexually cannibalistic praying mantis. Behavioral Ecolology and Sociobiology, 63: 313-320. DOI: $10.1007 / \mathrm{s} 00265-008-0663-8$

Pavićević D., Ivković S. \& Horvat L., 2014. New and rare species of orthopteroid insects in the fauna of
Serbia. Fauna Balkana University of Novi Sad, Serbia, 3: 103-122 .

Pushkar T. \& Kavurka V.V., 2016. New data about the distribution of Hierodula transcaucasica in Ukraine. Problems of Modern Entomology. Uzhgorod, 15-17 September 2016 Abstracts: 77-78. (in Russian).

Rebrina F., Battiston R. \& Skejo J., 2014. Are Empusa pennata and Bolivaria brachyptera really present in Croatia? A reply to Kranjčev (2013) with a critical review of mantid taxa found in Croatia. Entomologia Croatica, 18: 17-25.

Romanowski J. \& Romanowski M., 2014. Mantids (Mantodea) from Pelješac Peninsula, Southern Croatia. Entomologia Croatica, 18: 7-11.

Romanowski J., Battiston R. \& Hristov G., in press. First records of Hierodula transcaucasica Brunner von Wattenwyl, 1878 (Mantodea: Mantidae) in the Balkan peninsula. Acta Zoologica Bulgarica.

Schwarz C.J., Ehrmann R., Borer M. \& Monnerat C., 2018 Mantodea (Insecta) of Nepal: corrections and annotations to the checklist. In: Hartmann, Barclay \& Weipert: Biodiversität und Naturausstattung im Himalaya VI, pp. 201-247.

Van der Heyden T., 2018a. An interesting finding of a mantis on Crete/Greece (Dictyoptera: Mantodea: Mantidae: Mantinae: Paramantini). BV news Publicaciones Científicas, 7(99): 142-145.

Van der Heyden T., 2018b. First record of Hierodula transcaucasica Brunner von Wattenwyl (Mantodea: Mantidae: Mantinae: Paramantini) in Albania. Revista Chilena de Entomología, 44: 407-409.

Werner F., 1916. Zur Kenntnis afrikanischer und indischer Mantodeen. Verhandlungen der kaiserlichköniglichen zoologisch-botanischen Gesel-lschaft in Wien, 66: 254-296. 